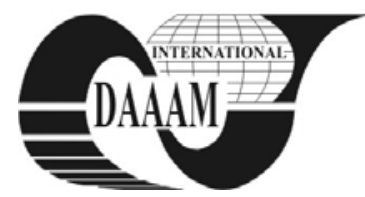

Annals of DAAAM for 2011 \& Proceedings of the 22nd International DAAAM Symposium, Volume 22, No. 1, ISSN 1726-9679 ISBN 978-3-901509-83-4, Editor B. Katalinic, Published by DAAAM International, Vienna, Austria, EU, 2011 Make Harmony between Technology and Nature, and Your Mind will Fly Free as a Bird Annals \& Proceedings of DAAAM International 2011

\title{
DEVELOPING A TIME BASED ELECTRICITY TARIFF
}

\section{TEICH, T[obias]; ROESSLER, F[alko]; SZENDREI, D[anny]; FRANKE, S[usan] \& LEONHARDT, S[ven]}

\begin{abstract}
The research project „Low Energy Living“ pursues the aim to create a techno-economic system to increase the energy efficiency in a network of lodgers, housing societies and providers (for example of electric power, thermal energy, natural gas or water). The necessary cross-linking and the use of different housing technologies like smart meters, heating and security installations for building automation with housekeeping and multimedia equipment is called intelligent living or, to be precise, smart home. These applications are connected and regulated by the established EIB/KNX field bus via electric cables, radio, double wire line or Ethernet. The technological basis for smart homes was developed to a great extent recently and is available at the market. Nevertheless, the potentials of these technologies aren't utilized to the full. Currently the housing technology and automation is deployed in commercial and public used large-scale buildings. In contrast to this the utilization of modern building technology in the living area is just at the beginning. For this reason, the target is to integrate intelligent building bus engineering and their automation on the basis of a demonstration object. Key words: smart metering, smart home, electricity tariff
\end{abstract}

\section{INTRODUCTION}

One subfield of the research project deals with the development of a variable electricity tariff for the local customers. The following article explains the pricing mechanism in Germany's energy market. Particularly with regard to the progressive liberalization of that market it covers the possibilities for creating variable tariff models. Existing concepts were discussed and as a result a new concept for implementation within the research project "Low Energy Living” must be developed. The target is to smooth the load profile. This gives the opportunity to reduce the annual electricity costs for each electricity consumers.

\section{PRICE FORMATION}

Until the liberalization in 1998 the German electricity prices were based on the average costs of production. Currently the calculated price for the end customers is derived from the purchase price on the European Electricity Exchange (EEX) plus taxes, duties, network access charges and distribution costs. The individual shares in the total electricity price were shown in Figure 1.

The purchase price is given by the intersection of the supply and demand function, which were generated via the different bids. The bids of the other bidders cannot be consulted. The thus formed equilibrium price is determined for each hour of the following day. All consumers, who are willing to pay this price, can be served. The purchase price occupies the biggest part of the total electricity price.

The other parts like taxes are regulated by law and cannot be influenced by the energy suppliers. For designing a variable tariff model the price fluctuations on energy market must be passed on to customers. As seen in Figure 2, the purchase price is fluctuating very strongly in the course of day.

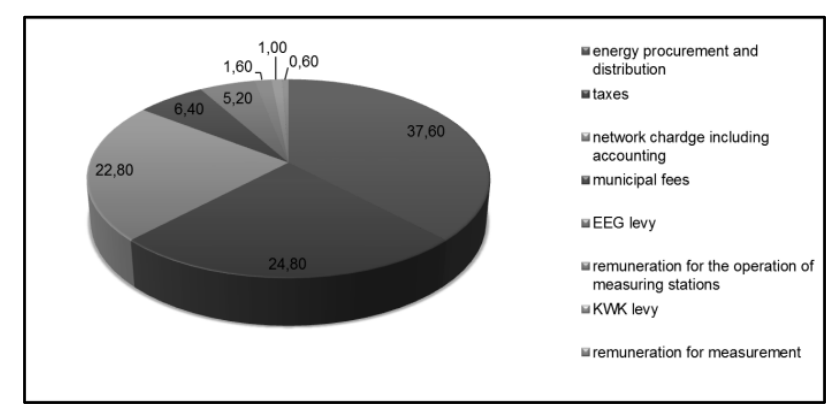

Fig. 1. Structure of the electricity price in Germany

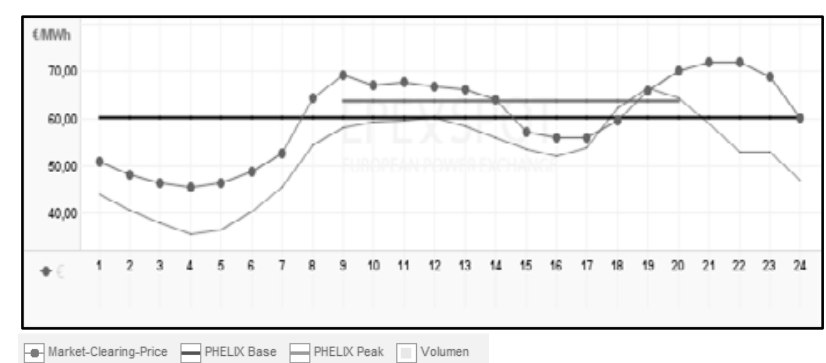

Fig. 1. Purchase electricity price at EEX

\section{LITERATURE OVERVIEW}

To make it possible to classify the concept for a variable tariff model presented in Chapter 4 it is necessary to explain two existing concepts.

\subsection{Locational Pricing, Nodal Pricing}

The concept of Locational Pricing respectively Nodal Pricing is respected as the ideal model in literature. The basis of this approach is the modeling of the electrical system considering different economic and technical specifications. Each producer and all greater load centers represent a single node. In addition all technical and economic performance indicators were determined either by a market mechanism or by a query. This model is used in the sense of the maximization of the economic total utility. Thereby each node represents its own submarket in which a price for electricity along with the fee for grid usage is determined. By optimizing the model it is possible to use each currently available line and to juice the most costeffective kin of generation and provision of electricity. Due to the large number of producers and consumers such a model is too complex for a realization in Europe or especially in Germany.

\subsection{The "Eckenförder Tariff"}

One of the first German projects concerning the displacement of consumption profiles is the research Project 
“Dynamische Stromtarife und Lastmanagement” which was carried out between 1994 and 1996. In a field trial 1000 randomly chosen households were analyzed. Their consumption was charged by a variable, continuously adjusted tariff. The basis of that experiment was the Peakload Pricing Model, which follows the course of marginal costs of producing electricity to determine the price function. As a result the load profile was smoothed by about $10 \%$. Along with that, electricity costs could be reduced by about $4,4 \%$. The one-off costs for the necessary equipment and additional infrastructure were amortized within three years. On the basis of inquiries of the participants a high customer satisfaction and acceptance could be proved.

\section{RECOMMENDATIONS FOR CONFIGURING A VARIABLE TARIFF MODEL}

Due to the economic crisis of the last years and the associated output drops, sales of the electricity suppliers have declined. The aim must be to introduce variable tariff models to preserve the customer base on the one hand and on the other hand to support the acquisition of new customers. It is necessary to implement incenitives for energy savings in the existing Peak load times

The technical and political restrictions within our research project:

- intelligent Smart Meter technology: the entire energy consumption of a house or a flat becomes totally transparent for customers

- dynamic tariff model cannot be calculated, because the local energy supplier purchases the electricity not a the dayahead market

To reduce the procurement costs, the electricity supplier must smooth the load profile at all. The following figure (Number 3) indicates the load peaks in Zwickau.

After the evaluation, different zones were surrendered. For example the highest demand for electricity is in the evening hours. The purchase price can be used as reference value. Following the load profile it is necessary to implement various price leaps within one day.

Within our research project we make the suggestion to implement 4 tariff times:

- Peak load time between 10 a.m. and 2 p.m.

- Major time between 8 and 10 a.m. and between 6 and 8 p.m.

- Low-peak time between 6 and 8 a.m. and between 2 and 6 p.m.

- Off-peak time between 8 p.m. and 6 a.m.

The price to be paid by the consumers is graded as follows:

- peak load time $100 \%$

- major time $80 \%$

- low-peak time $70 \%$

- off-peak time $50 \%$.

As a result of a forecast calculation it could be possible to save about $5 \%$ in comparison to previous electricity bill. The premises of these computations are that the load profile could be smoothening by about $8 \%$ and that the annual electricity consumption is up to $2000 \mathrm{kWh}$ annually.
Another starting point to reduce cost for suppliers and customers is the automation of accounting through standard ERP Software. To increase the image of the electricity suppliers and to enhance transparency about the customers' energy consumption, a web based information platform will be developed. Initial drafts are seen in figure 4.

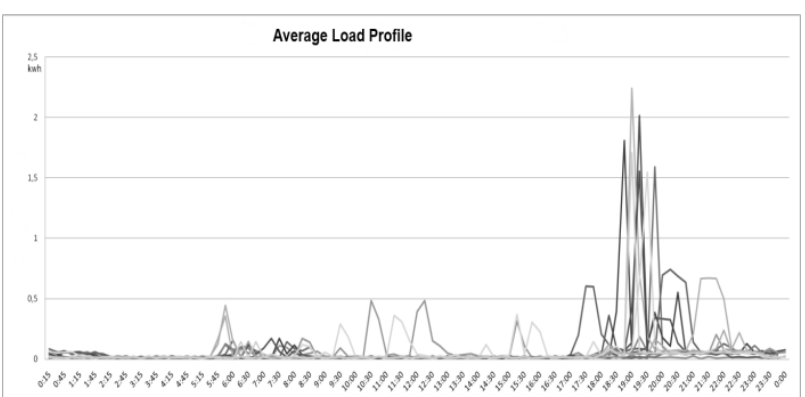

Fig. 2. Average load profile

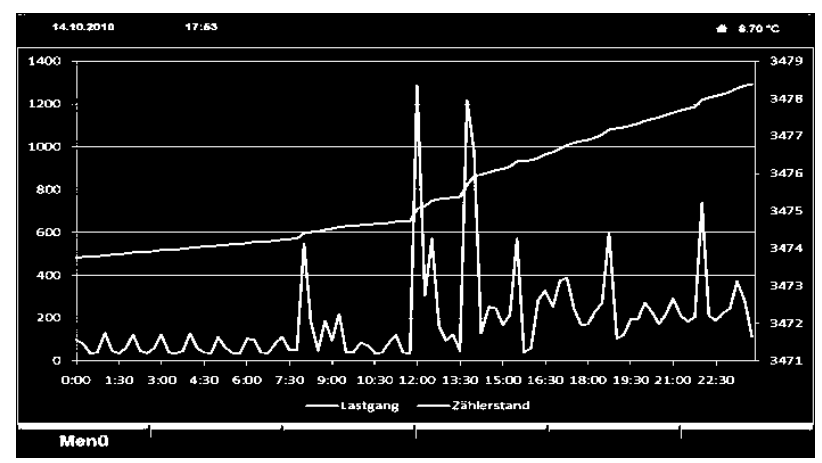

Fig. 4. information platform for customers

\section{CONCLUSION}

This article gives a short impression into the topic of designing variable tariff models in the electricity sector. The presented calculation example should examine possibilities for the introduction of such tariffs. In a further step, the practical implementation should be a priority.

\section{REFERENCES}

Franke, S. (2010). Tageszeitabhängige Tarifmodelle im Sektor Strom, In: Energieeffizienz in Wohngebäuden, GUC Verlag, 978-3-934235-89-2, Chemnitz

Morovic, T., Pilhar, R., Möhring-Hüser, W. (1998). Dynamische Stromtarife und Lastmanagement Erfahrungen und Perspektiven Kassel: Institut für Solare Energieversorgungstechnik (ISET)

Schober, D., Weber, C., Ziegler, D. (2008). Zusammensetzung der Strompreise in Europa: Endbericht; Studie im Auftrag des BDEW, Universität Duisburg-Essen, Lehrstuhl für Energiewirtschaft, Duisburg

Schwab, A.J. (2009) Elektroenergiesysteme: Erzeugung, Transport, Übertragung und Verteilung elektrischer Energie, Springer-Verlag, Berlin Heidelberg

Schittek, W. (2008). Strom - Fit für die Zukunft? Dynamischer Strompreis und virtuelle Sekundärregelung, Verlag Görich \& Weiershäuser, Marburg

Wawer, T. (2007) Konzepte für ein nationales Engpassmanagement im deutschen Übertragungsnetz, In: ZfE Zeitschrift für Energiewirtschaft 31 (2007)

*** (2010) http://www.zev-energie.de/pdf/geschaeftsbericht/ geschaeftsbericht_2009.pdf - Geschäftsbericht zum 31.12.2009 der Zwickauer Energieversorgung, Accessed on: $2010-10-19$ 